\title{
Pulmonary complications of antiviral drugs (Sofosbuvir and Daclatasvir) used in treatment of patients with chronic hepatitis C virus
}

Ibrahim Abd-Elfattah ${ }^{1}$ MD, Talaat Abd-Elaziz ${ }^{1}$ MD, Diaa Mohammed Elteiby ${ }^{2}$ MD, Eid Mohammed MSc ${ }^{1}$

\section{*CorrespondingAuthor: \\ Eid Mohammed \\ eidelagamy@yahoo.com Received for publication February, 5, 2020; Accepted February, 25, 2020; Published on line 4, 4, 2020.}

Copyright 2020 The Authors published by Al-Azhar University, Faculty of Medicine, Cairo, Egypt. All rights reserved. This an openaccess article distributed under the legal terms, where it is permissible to download and share the work provided it is properly cited. The work cannot be changed in anyway or used commercially

doi:10.21608/aimj.2020.21180. 1132

${ }^{1}$ Chest department, faculty of medicine, Al-Azhar University, Cairo, Egypt

${ }^{2}$ Endemic diseases and Tropical Medicine department, faculty of medicine, Al-Azhar

University, Cairo

\section{Abstract}

Background: Egypt has one of the highest hepatitis C virus (HCV) prevalence rates in the world, which led the government to strive to control it. The national guidelines for chronic HCV treatment had been modified to be interferon-free regimens by giving, the pan-genotypic direct acting antiviral agents (DAAs), sofosbuvir plus daclatasvir with or without ribavirin regimen. The aim of the study was the evaluation of the development of any considerable pulmonary complications among Egyptian patients receiving the combination of sofosbuvir plus daclatasvir for the treatment of chronic $\mathrm{HCV}$ infection.

Patients and Methods: The study included fifty patients with chronic $\mathrm{HCV}$ who were planned to be treated with sofosbuvir plus daclatasvir regimen. They were followed up during the course of the treatment to report and diagnose any developed respiratory symptoms, with two main stations of assessment (pre- and post-treatment), to compare between both outcomes.

Results: Nine patients (18\%) developed respiratory symptoms during this regimen, in the form of cough (16\%), sputum production $(6 \%)$, dyspnea (6\%), fever (6\%), and rhinorrhea (4\%). Their diagnoses were; acute bronchitis ( 2 patients), flu-like symptoms (2 patients), cough due to gastro-esophageal-reflux-disease (1 patient), mild airway hyperresponsiveness (1 patient), community-acquired pneumonia (1 patient), community-acquired pneumonia with para-pneumonic effusion (1 patient) and idiopathic pleural effusion (1 patient). They were managed without discontinuation of the regimen.

Conclusion: Sofosbuvir plus daclatasvir regimen was generally safe on the respiratory system, and some patients developed manageable nonserious respiratory events during the course of treatment.

Keywords: Pulmonary; Hepatitis C; Sofosbuvir; Daclatasvir; Airway hyper-responsiveness.

Disclosure: The authors have no financial interest to declare in relation to the content of this article. The Article Processing Charge was paid for by the authors.

\section{INTRODUCTION}

Hepatitis $\mathrm{C}$ virus (HCV) infection is a major global health challenge. Egypt has one of the highest HCV prevalence rate in the world, which led the Egyptian government to strive to control it through setting the 
it was associated with many drawbacks, including the respiratory adverse effects which ranged from mild interstitial pneumonitis to severe acute respiratory distress-like syndrome and death ${ }^{3,4}$.

After approval of direct-acting antivirals (DAAs), the Egyptian government modified the national guidelines to be interferon-free regimens, by giving the pan-genotypic regimen; sofosbuvir plus daclatasvir with or without ribavirin to all patients 4,5. More than one million Egyptian peoples were treated using DAAs with promising data and major progresses in the treatment of chronic hepatitis $\mathrm{C}^{6}$. DAAs have been characterized by very minimal adverse effects in the published clinical trials, however, data regarding the possibilities of the development of pulmonary adverse effects from the use of DAAs in the treatment of HCV patients are scarce in the literature.

The aim of the current study was directed towards the evaluation of the development of any considerable pulmonary complications among Egyptian patients receiving the combination of sofosbuvir plus daclatasvir for the treatment of chronic HCV infection.

\section{PATIENTS AND METHODS}

This study was carried out at "Chest Department, Al-Azhar University Hospitals, Cairo, Egypt" during the period between August 2016 and September 2019, on fifty patients with chronic HCV who were planned to be treated with sofosbuvir plus daclatasvir without ribavirin regimen. Informed consent was obtained from all patients, and the local Ethical Committee has approved the study.

The following patients were excluded from the study: Smokers, those with known chronic pulmonary disease, those with accidentally discovered abnormalities in the chest radiography, pulmonary function test or bronchial challenge test in the pre-treatment station, those with recent upper respiratory tract viral infection and those currently receiving herbal medicine or any medication that known to affect the airway tone or responsiveness, those with cirrhotic liver or hepatocellular carcinoma, those who discontinued the course of the sofosbuvir plus daclatasvir treatment due to nonrespiratory adverse events, and those who were contraindicated for spirometry or methacholine challenge test.

The patients were followed up during the usual duration of treatment (12 weeks); to report and investigate any developed respiratory symptoms, with two main stations of assessment (pre- and posttreatment). In both pre- and post-treatment stations, all patients underwent a basal and final clinical and laboratory assessment, chest radiography, spirometry carried out on Medisoft MICRO 5000 device and methacholine challenge test (MCT) carried out on Medisoft MICRO 5000 PROVO 4 device using Acetyl- $\beta$-methylcholine chloride. Then comparison was made between both outcomes, with evaluation of the symptomatic cases and their final diagnosis.

\section{Statistical analysis:}

The data were collected, coded, revised, verified, and computerized. Statistical analyses were done using SPSS statistical package version 16. (IBM Corp, Chicago, IL, USA) Qualitative data were presented in the form of numbers and percentages and quantitative variables as mean and standard deviation (SD). A comparison between quantitative variables was carried out by the student T-test of two independent samples. Chi-square test (X2), was used to compare qualitative variables.

\section{RESULTS}

Fifty patients were included in this study, their age was ranged from 20 to 66 years with the mean of 45 \pm 11.31 , and the body mass index (BMI) was ranged from 20 to 34 with the mean of $28 \pm 3$. Sixty two percent $(62 \%)$ of the included patients were males while $38 \%$ of them were females. Sixty four percent $(64 \%)$ of them were from rural areas while $36 \%$ of them were from urban areas. Thirty percent (30\%) of them had comorbidities, which were intermingled and distributed as diabetes (16\%), hypertension (20\%), dyslipidemia (4\%), gastro-esophagealreflux-disease $(4 \%)$ and ischemic heart disease (2\%).

The study showed that the sofosbuvir plus daclatasvir regimen notably normalized the elevated liver enzymes. But, there were no statistically significant changes in the haemoglobin, white blood cells, platelets count, bilirubin, creatinine, spirometric findings and MCT findings in those treated with this regimen (tables 1 and 2).

Three patients had positive airway hyperresponsiveness (AHR) in the post-treatment station assessment, and only one of them was symptomatized by cough that explained as mild airway hyper-responsiveness, while the other two patients were asymptomatic and showed borderline airway hyper-responsiveness. However, there were no statistically significant differences between the pre-and post-treatment methacholine challenge test parameters (table 3 ).

Nine patients (18\%) developed respiratory symptoms during this course of sofosbuvir plus daclatasvir treatment in the form of cough (16\%), sputum production $(6 \%)$, dyspnea $(6 \%)$, fever $(6 \%)$, and rhinorrhea $(4 \%)$. There were no statistically significant differences in distributing the patients according to the development of the respiratory symptoms during the course of treatment in relation to the age, sex and residence of the patients. Also, there were no statistically significant differences in correlating the development of the respiratory 
symptoms during the course of treatment to the results of pre-treatment liver enzymes or posttreatment methacholine challenge test.

The diagnosis of those nine symptomatic patients was; acute bronchitis (2patients), flu-like symptoms (2patients), cough due to gastro-esophageal-refluxdisease (1patient), mild airway hyperresponsiveness (1patient), community-acquired pneumonia (1patient), community-acquired pneumonia with para-pneumonic effusion (1 patient) and idiopathic pleural effusion (1 patient) They were managed without discontinuation or modification in the sofosbuvir plus daclatasvir regimen

\begin{tabular}{|c|c|c|c|c|}
\hline $\begin{array}{r}\text { Paramet } \\
\text {-er }\end{array}$ & \multicolumn{2}{|c|}{ Range } & Mean \pm SD & $\begin{array}{r}\text { p- } \\
\text { value }\end{array}$ \\
\hline \multirow{2}{*}{$\begin{array}{r}\text { Haemogl } \\
\text { ob-in } \\
(\mathrm{mg} / \mathrm{dl})\end{array}$} & $\begin{array}{l}\text { Pre- } \\
\text { treatment }\end{array}$ & $\begin{array}{r}10.5- \\
14.7\end{array}$ & $13.194 \pm 1.04$ & \multirow{2}{*}{0.376} \\
\hline & $\begin{array}{l}\text { Post- } \\
\text { treatment }\end{array}$ & $10-14.8$ & $13.108 \pm 1.06$ & \\
\hline \multirow{2}{*}{$\begin{array}{r}\text { White } \\
\text { blood } \\
\text { cells } \\
\left(10^{9} / \mathrm{L}\right)\end{array}$} & $\begin{array}{l}\text { Pre- } \\
\text { treatment }\end{array}$ & 4.4-9.1 & $6.592 \pm 1.31$ & \multirow{2}{*}{0.854} \\
\hline & $\begin{array}{l}\text { Post- } \\
\text { treatment }\end{array}$ & $4.9-9.7$ & $6.560 \pm 1.22$ & \\
\hline \multirow{2}{*}{$\begin{array}{l}\text { Platelets } \\
\qquad\left(10^{9} / \mathrm{L}\right)\end{array}$} & $\begin{array}{l}\text { Pre- } \\
\text { treatment }\end{array}$ & $164-394$ & $247.42 \pm 56.8$ & \multirow{2}{*}{0.597} \\
\hline & $\begin{array}{l}\text { Post- } \\
\text { treatment }\end{array}$ & $134-376$ & $\begin{array}{r}245.88 \pm \\
56.35\end{array}$ & \\
\hline \multirow{2}{*}{$\begin{array}{r}\text { ALT } \\
(\mathrm{IU} / \mathrm{L})\end{array}$} & $\begin{array}{l}\text { Pre- } \\
\text { treatment }\end{array}$ & $20-79$ & $52.88 \pm 13.14$ & \multirow{2}{*}{$\begin{array}{r}< \\
0.001\end{array}$} \\
\hline & $\begin{array}{l}\text { Post- } \\
\text { treatment }\end{array}$ & $18-54$ & $33.98 \pm 9.612$ & \\
\hline \multirow{2}{*}{$\begin{array}{c}\text { AST } \\
(\mathrm{IU} / \mathrm{L})\end{array}$} & $\begin{array}{l}\text { Pre- } \\
\text { treatment }\end{array}$ & $19-60$ & $36.90 \pm 10.25$ & \multirow{2}{*}{$\begin{array}{r}< \\
0.001\end{array}$} \\
\hline & $\begin{array}{l}\text { Post- } \\
\text { treatment }\end{array}$ & $16-38$ & $23.44 \pm 4.76$ & \\
\hline \multirow{2}{*}{$\begin{array}{r}\text { Total } \\
\text { bilirubin } \\
(\mathrm{mg} / \mathrm{dl})\end{array}$} & $\begin{array}{l}\text { Pre- } \\
\text { treatment }\end{array}$ & $0.2-1.2$ & $0.75 \pm 0.26$ & \multirow{2}{*}{0.950} \\
\hline & $\begin{array}{l}\text { Post- } \\
\text { treatment }\end{array}$ & $0.3-1.2$ & $0.75 \pm 0.23$ & \\
\hline \multirow{2}{*}{$\begin{array}{l}\text { Albumin } \\
\qquad(\mathrm{g} / \mathrm{dl})\end{array}$} & $\begin{array}{l}\text { Pre- } \\
\text { treatment }\end{array}$ & $3.6-4.7$ & $4.13 \pm 0.27$ & \multirow{2}{*}{0.935} \\
\hline & $\begin{array}{l}\text { Post- } \\
\text { treatment }\end{array}$ & $3.5-4.8$ & $4.13 \pm 0.29$ & \\
\hline \multirow{2}{*}{$\begin{array}{r}\text { Creatinin } \\
\mathrm{e} \\
(\mathrm{mg} / \mathrm{dl})\end{array}$} & $\begin{array}{l}\text { Pre- } \\
\text { treatment }\end{array}$ & $0.6-1.1$ & $0.85 \pm 0.16$ & \multirow{2}{*}{0.814} \\
\hline & $\begin{array}{l}\text { Post- } \\
\text { treatment }\end{array}$ & $0.6-1.1$ & $0.85 \pm 0.17$ & \\
\hline
\end{tabular}

Table (1): Comparison between pre- and posttreatment laboratory findings among the studied population.

\begin{tabular}{|c|c|c|c|c|c|}
\hline Para & eter & $\begin{array}{c}\text { Rang } \\
\text { e }\end{array}$ & $\begin{array}{c}\text { Mean } \pm \\
\text { SD }\end{array}$ & $\mathbf{T}$ & $\begin{array}{r}\text { p- } \\
\text { valu } \\
\text { e }\end{array}$ \\
\hline (A)Spiron & try & & & & \\
\hline FVC & $\begin{array}{l}\text { Pre- } \\
\text { treatme } \\
\text { nt }\end{array}$ & $\begin{array}{r}80.65 \\
-99.2\end{array}$ & $\begin{array}{r}91.10 \pm \\
4.606\end{array}$ & 190 & 006 \\
\hline $\begin{array}{c}\text { predicted } \\
\text { ) }\end{array}$ & $\begin{array}{l}\text { Post- } \\
\text { treatme } \\
\text { nt }\end{array}$ & $\begin{array}{r}81.03 \\
- \\
99.63\end{array}$ & $\begin{array}{r}90.71 \pm \\
4.220\end{array}$ & 0 & 3 \\
\hline $\mathrm{FEV}_{1}$ & $\begin{array}{l}\text { Pre- } \\
\text { treatme } \\
\text { nt }\end{array}$ & $\begin{array}{r}80.18 \\
- \\
99.38\end{array}$ & $\begin{array}{r}92.17 \pm \\
4.106\end{array}$ & ר 07 & 002 \\
\hline $\begin{array}{r}\text { predicted } \\
\text { ) }\end{array}$ & $\begin{array}{l}\text { Post- } \\
\text { treatme } \\
\text { nt }\end{array}$ & $\begin{array}{r}82.40 \\
- \\
99.12\end{array}$ & $\begin{array}{r}92.14 \pm \\
4.050\end{array}$ & 6 & 9 \\
\hline FEV & $\begin{array}{l}\text { Pre- } \\
\text { treatme } \\
\text { nt }\end{array}$ & $\begin{array}{r}81.52 \\
- \\
89.24\end{array}$ & $\begin{array}{r}84.68 \pm \\
3.015\end{array}$ & & 0.58 \\
\hline & $\begin{array}{l}\text { Post- } \\
\text { treatme } \\
\text { nt }\end{array}$ & $\begin{array}{r}79.59 \\
- \\
91.54\end{array}$ & $\begin{array}{r}84.89 \pm \\
3.286\end{array}$ & 4 & 9 \\
\hline (B) Met & holine c & gge $t$ & (MCT) & & \\
\hline $\begin{array}{l}\% \text { of } \\
\text { decrease } \\
\text { from the }\end{array}$ & $\begin{array}{l}\text { Pre- } \\
\text { treatme } \\
\text { nt }\end{array}$ & $\begin{array}{c}7- \\
13 \%\end{array}$ & $\begin{array}{c}9.85 \% \pm \\
1.55\end{array}$ & & \\
\hline $\mathrm{FEV}_{1}$ & $\begin{array}{l}\text { Post- } \\
\text { treatme } \\
\text { nt }\end{array}$ & $\begin{array}{c}5- \\
24 \%\end{array}$ & $\begin{array}{c}10.44 \% \\
\pm 3.69\end{array}$ & 4 & 2 \\
\hline
\end{tabular}

Table (2): Comparison between pre- and posttreatment spirometric and MCT parameters among the studied population.

\begin{tabular}{|l|l|l|}
\hline \multicolumn{1}{|c|}{ Interpretation } & Number & \% \\
\hline Negative & 47 & $94 \%$ \\
\hline Borderline AHR & 2 & $4 \%$ \\
\hline Mild AHR & 1 & $2 \%$ \\
\hline Total & 50 & 100 \\
\hline
\end{tabular}

Table (3): Post-treatment MCT interpretation.

\section{DISCUSSION}

Direct-acting Antivirals (DAAs) have significantly improved the tolerability and efficacy of $\mathrm{HCV}$ treatment, and have been characterized by very minimal adverse effects in the published clinical trials, however, patients should always be managed with caution to avoid the side effects of therapy ${ }^{7}$. A 
data regarding the possibilities of the development of pulmonary adverse effects from the use of DAAs in the treatment of $\mathrm{HCV}$ patients is scarce in the literature.

The present study showed that the sofosbuvir plus daclatasvir regimen for 12 weeks notably ameliorated the elevated liver enzymes, with statistically significant changes between pretreatment and post-treatment results. However, there were no statistically significant changes between pre-treatment and post-treatment results of hemoglobin, white blood cells, platelets count, bilirubin and creatinine. These findings are not surprising, as they were documented by several studies $8,9,10,11,12$.

On the other hand, the spirometric results (FVC, FEV1, FEV1/FVC\%) of the included patients in the current study were normal in both stations with no statistically significant changes. This result agrees with the result of the study done by Aboud et al. ${ }^{12}$, but it disagreed with that of Abouelkheir et al. ${ }^{13}$ who found a reduction in FEV1 and FEV1/FVC\%, and the obstructive ventilatory defect was the prominent pattern in their study on patients treated with sofosbuvir plus daclatasvir with ribavirin regimen. The results of Abouelkheir et al. study were different from the results of our study, because they used ribavirin in their regimen, and they didn't exclude smokers or patients with cirrhotic liver from their study.

The current study showed that all patients had negative AHR in the pre-treatment station and only three of them (6\%) changed to positive AHR in the post-treatment station. Only one of those three patients with the positive AHR was symptomatized by cough during the 10th week of the sofosbuvir plus daclatasvir treatment and explained as mild AHR, and he completed the course of treatment without discontinuation or modification in the regimen. The other two patients were asymptomatic and showed borderline AHR. However, there were no statistically significant differences between the pre- treatment and post-treatment MCT parameters. Up till now, there is no published study on the assessment of AHR in chronic HCV patients treated with sofosbuvir plus daclatasvir regimen or other DAAs used in HCV treatment.

In this study, nine patients (18\%) experienced respiratory symptoms during the course of sofosbuvir plus daclatasvir regimen as detailed in figure 1. However, these symptoms were mild, manageable and did not require discontinuation or modification of the sofosbuvir plus daclatasvir regimen. These symptoms were reported together or separately in multiple studies $\mathbf{9 , 1 0 , 1 1 , 1 2 , 1 3 , 1 4}$, but other studies didn't report any respiratory adverse effects during the sofosbuvir plus daclatasvir regimens for $\mathrm{HCV}$ treatment, and they reported that sofosbuvir plus daclatasvir combination was well tolerated without serious adverse events $15,16,17$.

The diagnosis of those nine patients who were symptomatic in this study was variable and detailed in figure 2. These results also reported in the few studies that were interested in reaching the final diagnosis of the reported respiratory symptoms in $\mathrm{HCV}$ patients received sofosbuvir plus daclatasvir regimen ${ }^{9,10,13,14,18}$.

The nine symptomatic patients were managed and improved irrelevantly to the course of sofosbuvir plus daclatasvir regimen except two cases; one diagnosed as mild airway hyperresponsiveness and the other was idiopathic pleural effusion (exudative with a predominant lymphocytosis and negative histopathological thoracoscopic pleural biopsy), and both noticed improvement within weeks of completion of the sofosbuvir plus daclatasvir regimen. However, on follow up the patient with idiopathic pleural effusion developed recurrent pleural effusion after seven months and diagnosed as mesothelioma via histopathology of another thoracoscopic pleural biopsy. Although, the causal relation between the development of mesothelioma and sofosbuvir plus daclatasvir regimen in this patient was unreliable, as the residence of the patient in an area contaminated by asbestos can give an explanation for this finding.

The distribution of the patients according to the development of the respiratory symptoms during the course of treatment in relation to their age, sex and residence showed that there were no statistically significant differences. Also, the correlation of the development of the respiratory symptoms during the $\mathrm{HCV}$ treatment and the pre-treatment liver enzymes or post-treatment MCT showed that there were no statistically significant differences.

All of the symptomatic patients in this study were managed without discontinuation or modification in sofosbuvir plus daclatasvir regimen, and none of them had a serious adverse effect that lead to premature discontinuation of treatment and no deaths occurred. This result agrees with the studies done by Babatin et al. ${ }^{8}$, Ahmed et al. ${ }^{9}$, ElGammal et al. ${ }^{10}$, Abdel-Moneim et al. ${ }^{11}$ and Aboud et al. ${ }^{12}$ Abouelkheir et al. ${ }^{13}$, Osman et al. ${ }^{14}$. However, few studies reported adverse effects that led to discontinuation of the sofosbuvir plus daclatasvir regimen in a few patients, and they were diagnosed as severe asthma exacerbation ${ }^{19}$, and an acute respiratory failure secondary to chronic obstructive pulmonary disease exacerbation 20 . However, any patient with a known respiratory disease was excluded from our study.

\section{CONCLUSION}

The sofosbuvir plus daclatasvir regimen used for the treatment of chronic HCV Egyptian patient was generally safe on the respiratory system. Some patients developed a manageable non-serious 
respiratory manifestations, but the causality relation between with the sofosbuvir and daclatasvir regimen cannot be proved,

Further studies are recommended on a larger scale of chronic $\mathrm{HCV}$ infected patients with different comparative categories.

\section{REFERENCES}

1. WHO Fact sheets: Hepatitis C; World Health Organization. Updated July 2019, Accessed December 2019. Available at https://www.who.int/en/news-room/factsheets/detail/hepatitis-c.

2. Gomaa A, Allam N, Elsharkawy A, El Kassas $\mathbf{M}$, et al. Hepatitis $\mathbf{C}$ infection in Egypt: prevalence, impact and management strategies. Hepatic Medicine: Evidence and Research Volume, 2017; 9: 17-25.

3. Elhelaly S, Elgazzar A, Ragab M, Elkomy H, et al. Pulmonary hazards of chronic hepatitis $\mathrm{C}$ virus infection treatment with pegylated interferon and ribavirin vs. untreated patients. Egyptian Journal of Chest Diseases and Tuberculosis, 2013; 62: 325-329.

4. El-Akel W, El-Sayed M, El Kassas M, ElSerafy M, et al. National treatment programme of hepatitis C in Egypt: Hepatitis C virus model of care. Journal of Viral Hepatitis., 2017; 24(4):262-267.

5. Youssef N, El Kassas M, Farag A and Shepherd. Health-related quality of life in patients with chronic hepatitis $\mathrm{C}$ receiving sofosbuvir-based treatment, with and without Interferon: a prospective observational study in Egypt. BMC Gastroenterology, 2017; 17(1):18.

6. WHO global Hepatitis Report: Geneva: World Health Organization; 2017. Available on www.who.int.

7. Banerjee D and Reddy R. Safety and tolerability of direct-acting anti-viral agents in the new era of hepatitis $C$ therapy. Alimentary Pharmacology \& Therapeutics, 2016; 43(6): 674-696.

8. Babatin A, Alghamdi S, Albenmousa A, Alaseeri A, et al. Efficacy and safety of simeprevir or daclatasvir in combination with sofosbuvir for the treatment of hepatitis C genotype 4 infection. Journal of Clinical Gastroenterology, 2018; 52(5): 452-457.

9. Ahmed E, Abdel Wahed W, Hassan E, and Ahmed T. Study of adverse drug effects of direct-acting antivirals for chronic $\mathrm{HCV}$ infection at Fayoum governorate, Egypt - A pharmacovigilance study. Current Drug Safety, 2018; 13: 187-195.

10. El-Gammal N, Shahin N and Abdelkader H. Efficacy and adverse effects of sofosbuvir plus daclatasvir therapy in chronic HCV patients in
Sharkia governorate, Egypt. Afro-Egypt Journal of Infectious and Endemic Diseases, 2018; 8(4):174-181.

11. Abdel-Moneim A, Aboud A, Abdel-Gabaar M, Zanaty $M$, et al. Efficacy and safety of sofosbuvir plus daclatasvir with or without ribavirin: large real-life results of patients with chronic hepatitis C genotype 4. Hepatology International, 2018: 12:348-355.

12. Aboud A, Anwer L and Soliman M. Study of the effect of sofosbuvir and daklatasivir on respiratory system in patients with chronic hepatitis C. Open Journal of Gastroenterology and Hepatology, 2019; 2:11-16.

13. Abouelkheir D, Elhadidy $\mathrm{T}$, Besheer $\mathrm{T}$ and Farag R. Respiratory adverse effects of sofosbuvir-based regimens for treatment of chronic hepatitis C virus. Egyptian Journal of Chest Diseases and Tuberculosis, 2017; 66(2):363-367.

14. Osman M, Elsaeid K, Mosa N, Abou Bakr S, et al. Comparison between different lines of antiviral combination therapies against hepatitis $\mathrm{C}$ virus genotype 4 in Egyptian patients. The Egyptian Journal of Hospital Medicine, 2018, 72 (9): 5326-5333.

15. Nelson D, Cooper J, Lalezari J, Lawitz E, et al. All-oral 12-week treatment with daclatasvir Plus sofosbuvir in patients with hepatitis C virus genotype-3 infection: ALLY-3 Phase III Study, World Journal of Hepatology, 2015; 61: 1127-1135.

16. Nappi A, Perrella A, Bellopede P, Lanza A, et al. Safety of new DAAs for chronic HCV infection in a real life experience: role of a surveillance network based on clinician and hospital pharmacist. Infectious Agents and Cancer, 2017; 12: 12-16.

17. Abdel-Aziz M, Ibrahim M, El-Sheikh A, Kamel M, et al. Effect of sofosbuvir plus daclatasvir in hepatitis $\mathrm{C}$ virus genotype-4 patients: promising effect on liver Fibrosis. Journal of Clinical and Experimental Hepatology, 2017; 6:1-8.

18. Attia D, El Saeed K, Elakel W, Esmat G, et al. The adverse effects of interferon-free regimens in 149,816 chronic hepatitis C treated Egyptian patients. Alimentary Pharmacology \& Therapeutics, 2018; 47:1296-1305.

19. Omar H, El Akel W, Elbaz T, El Kassas M, et al. Generic daclatasvir plus sofosbuvir, with or without ribavirin, in treatment of chronic hepatitis C: real-world results from 18,378 patients in Egypt. Alimentary Pharmacology \& Therapeutics, 2018; 47(3): 421-431.

20. Elbaz T, Abdo M, Omar H, Hassan E, et al. Efficacy and safety of sofosbuvir and daclatasvir with or without ribavirin in elderly patients with chronic hepatitis $\mathrm{C}$ virus infection. Journal of Medical Virology, 2019; 91(2): 272-277. 